\section{Response of Creeping Bentgrass to Nitrogen and Ethephon}

\author{
Patrick E. McCullough ${ }^{1}$ \\ Department of Plant Biology and Pathology, Rutgers, The State University of \\ New Jersey, New Brunswick, NJ 08901-8520 \\ Haibo Liu' ${ }^{2}$ and Lambert B. McCarty
Department of Horticulture, Clemson University, Clemson, SC 29634-0375
}

Additional index words. phytotoxicity, plant growth regulator, root growth

\begin{abstract}
Ethephon is an effective growth retardant for suppressing Poa annua (L.) seedheads in creeping bentgrass putting greens; however, ethylene induction may cause bentgrass leaf chlorosis, reduced rooting, and quality decline. Two greenhouse experiments investigated the effects of nitrogen $(N)$ fertility and ethephon applications on ' $L-93$ ' creeping bentgrass over 9 weeks. Ethephon was applied at $0,3.8$, and $7.6 \mathbf{~ k g}^{\circ} \mathbf{h a}^{-1}$ a.i. per 3 weeks and $N$ was applied at 4 and $8 \mathrm{~kg} \cdot \mathrm{ha}^{-1} \cdot$ week $^{-1}$. Ethephon applications linearly reduced bentgrass quality on every weekly observation. Increased N rate to $8 \mathrm{~kg} \cdot \mathrm{ha}^{-1} \cdot \mathrm{week}^{-1}$ improved turf quality about $10 \%$ to $20 \%$ and $10 \%$ to $30 \%$ from ethephon applied at 3.8 and $7.6 \mathrm{~kg} \cdot \mathrm{ha}^{-1}$ per 3 weeks, respectively. Increased $\mathrm{N}$ rate to $8 \mathrm{~kg} \cdot \mathrm{ha}^{-1} \cdot \mathrm{week}^{-1}$ enhanced shoot growth $30 \%$ but reduced root mass and length $12 \%$ and $11 \%$, respectively. After 9 weeks, ethephon reduced root length by about $30 \%$ and root mass about $35 \%$ at both rates. From nine weekly samples, ethephon reduced dry clipping yield $10 \%$ and $16 \%$ at 3.8 and $7.6 \mathrm{~kg} \cdot \mathrm{ha}^{-1}$ per 3 weeks, respectively. From 2 to 9 weeks after initial treatments, ethephon linearly increased leaf water content. Increasing $\mathbf{N}$ fertility effectively reduced bentgrass leaf chlorosis from ethephon; however, repeat applications of ethephon and increased $\mathbf{N}$ may restrict bentgrass root growth. Chemical names used: [(2-chloroethyl)phosphonic acid] (ethephon).
\end{abstract}

Creeping bentgrass (Agrostis stolonifera Huds.) with heavy Poa annua (L.) infestations requires intensive management to produce commercially acceptable putting green surfaces (Engel and Illnicki, 1969; McCarty et al., 2005a). Compared to creeping bentgrass, $\mathrm{Poa}$ annua has a lighter green color, courser texture, and produces unsightly seedheads which may disrupt surface uniformity and decrease ball roll distances (Beard, 1973). Since selective herbicides for established Poa annua control are currently not available in creeping bentgrass putting greens, plant growth regulators (PGRs) are commonly applied to suppress its growth and seedhead formation.

Ethephon is a PGR currently used in the turf industry for Poa annua management in bentgrass golf greens. When reacted with water, ethephon diffuses to ethylene which inhibits growth by signaling damage, stress, or injury to plant cells (Taiz and Zeiger, 2002). Ethylene release also delays flowering, selectively aborts flowers, and reduces stem elongation (Serek and Reid, 2000). Furthermore, changes in hormone balance favoring ethylene create a lower cytokinin ratio with less energy directed towards cell division required for seedhead emergence. With these unique properties, ethephon effectively arrests Poa annua seedhead formation in creeping bentgrass putting greens (Eggens et al., 1989; Gelertner and

Received for publication 15 June 2004. Accepted for publication 23 Nov. 2004

${ }^{1}$ Program associate.

${ }^{2}$ Associate professor. To whom reprint requests should be addressed; e-mail haibol@clemson.edu. ${ }^{3}$ Professor.
Stowell, 2001). However, leaf senescence and chlorophyll breakdown from ethylene induction may reduce bentgrass color and turf density, thus limiting the use of ethephon for putting green turf.

Routine nitrogen $(\mathrm{N})$ fertility may significantly influence plant responses to ethephon applications. Nitrogen is the mineral nutrient required in greatest amounts by turfgrasses and when appropriately applied promotes color, vigor, and stress tolerance (Beard, 1973; Turner and Hummell, 1992). Nitrogen is also a key constituent of chlorophyll, which may be a critical factor in reducing leaf chlorosis following ethephon applications. Creeping bentgrass putting greens require about 4 to 8 $\mathrm{kg} \cdot \mathrm{ha}^{-1} \mathrm{~N}$ per week to maintain desired color and compensate for nutrient loss through routine clipping collection (McCarty et al., 2005b).

Since ethephon is used for Poa annua seedhead suppression in putting green turf, masking creeping bentgrass color decline may be critical when applying this PGR. The objective of this experiment was to investigate growth responses of ' $L-93$ ' creeping bentgrass to ethephon and $\mathrm{N}$ fertility.

\section{Materials and Methods}

Nine week greenhouse experiments were conducted at the Clemson University Greenhouse Research Complex, Clemson, S.C., from December 2003 to February 2004 and from April to June 2004. Greenhouse day/night temperatures were set for about $26 / 20^{\circ} \mathrm{C}$. Due to reduced natural lighting during winter months, the experimental design was a randomized complete block with three replications of six polyvinylchloride containers per block (two N rates and three ethephon rates). Supplemental lighting was added for about $3 \mathrm{~h} \cdot \mathrm{d}^{-1}$ at 50 $\mu \mathrm{mol} \cdot \mathrm{m}^{-2} \cdot \mathrm{s}^{-1}$. Blocks were rotated every three weeks and re-randomized within.

'L-93' creeping bentgrass plugs were collected from an experimental putting green located at the Turf Service Center, Clemson, established in August 2002. Turf plugs were washed free of soil and roots were cut to about $2.5 \mathrm{~cm}$ from the thatch layer. Plugs were then transplanted to polyvinyl chloride containers constructed approximately to United States GolfAssociation specifications (USGA Green Section Staff, 1993) to mimic field conditions. A 85 sand : 15 peatmoss (by volume) rootzone mix consisting of $6 \%$ coarse sand $(0.5$ to 1.0 $\mathrm{mm}), 30 \%$ medium sand $(0.25$ to $0.5 \mathrm{~mm})$, $48 \%$ fine sand ( 0.1 to $0.25 \mathrm{~mm}$ ), and $16 \%$ very fine sand $(<0.1 \mathrm{~mm})$ was used. Containers had $40 \mathrm{~cm}$ depths with $177-\mathrm{cm}^{2}$ surface areas and had drainage holes cut at about 6 $\mathrm{mm}$ diameters at the bottom. A starting fertilizer $\left(9 \mathrm{~N}-18 \mathrm{P}_{2} \mathrm{O}_{5}-17 \mathrm{~K}_{2} \mathrm{O}\right.$; Scott's, Marysville, Ohio) was mixed into the soil at $48 \mathrm{~kg} \cdot \mathrm{ha}^{-1} \mathrm{~N}$. The fertilizer also contained $\mathrm{Ca}, \mathrm{Mg}$, and $\mathrm{S}$ at $4 \%, 2 \%$, and $7 \%$, respectively.

Turf was established 3 weeks before initial ethephon treatments. Bentgrass was mowed at about $4 \mathrm{~mm}$ mowing height with automatic grass sheers (Black and Decker, Towson, Md.) and watered to field capacity $5 \mathrm{~d} \cdot$ week $^{-1}$. Ethephon (2L) was applied at $0,3.8$, and 7.6 $\mathrm{kg} \cdot \mathrm{ha}^{-1}$ a.i. per 3 weeks with a greenhouse spray chamber, Devries Manufacturing (Hollandale, Minn.) delivering $720 \mathrm{~L} \cdot \mathrm{ha}^{-1}$. Beginning five days after initial ethephon applications, ammonium nitrate $\left(34 \mathrm{~N}-\mathrm{OP}_{2} \mathrm{O}_{5}-0 \mathrm{~K}_{2} \mathrm{O}\right)$ solution was applied at 4 and $8 \mathrm{~kg} \cdot \mathrm{ha}^{-1} \mathrm{~N}$ per week.

Bentgrass quality ratings were evaluated weekly on a 1 to 9 scale with 1 equal to completely dormant or brown turf and 9 equal to dark green, uniform turf. Clippings were harvested weekly, oven dried at $80{ }^{\circ} \mathrm{C}$ for $48 \mathrm{~h}$, and then weighed. Before oven drying, fresh weight clipping yield was recorded and leaf water content estimated by the following formula: leaf water content $=1-($ dry weight clippings/fresh weight clippings).

Roots were harvested from the entire container after 9 weeks, oven-dried, and then weighed. Root length was determined by measuring the distance from where roots were no longer present in the soil profile to the top of the container. Data analyses were made using the analysis of variance with SAS General Linear Model procedure (SAS Institute, 1999). Orthogonal polynomial contrasts examined linear and quadratic relationships between plant response and level of ethephon. Study by treatment interactions did not occur for any parameters; therefore; the two studies were combined.

\section{Results and Discussion}

Bentgrass visual quality linearly decreased with ethephon rates on every weekly observation (Table 1). Similar reductions in turf quality have been observed in cool and warm 
Table 1. Visual quality of 'L-93' creeping bentgrass treated with nitrogen and ethephon in two combined greenhouse experiments.

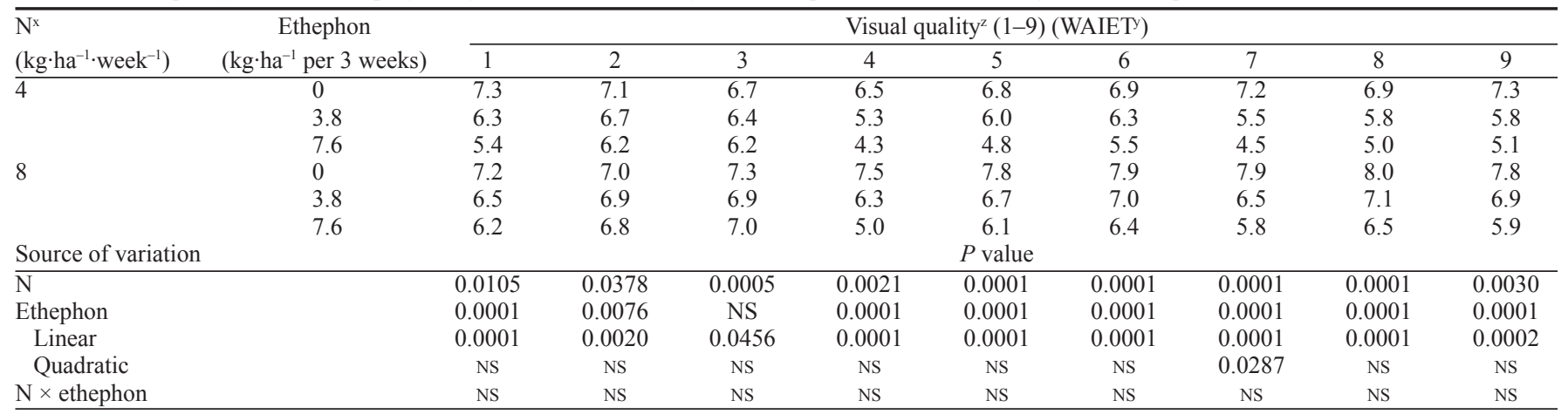

${ }^{2}$ Visual quality was rated 1 to 9 where $1=$ dead turf and $9=$ dark green, uniform turf; ratings below 7 were unacceptable.

${ }^{y}$ WAIET $=$ week after initial ethephon treatment.

${ }^{x}$ Ammonium nitrate (34-0-0) was the nitrogen source.

Table 2. Dry clipping yield for 'L-93' creeping bentgrass in two combined greenhouse experiments.

\begin{tabular}{lc}
\hline Treatment & $\begin{array}{c}\text { Clipping } \\
\text { yieldy } \\
\left(\mathrm{g} \cdot \mathrm{m}^{-2}\right)\end{array}$ \\
\hline $\mathrm{N}^{2}\left(\mathrm{~kg} \cdot \mathrm{ha}^{-1} \cdot \mathrm{week}^{-1}\right)$ & 0.75 \\
4 & 0.97 \\
Ethephon $\left(\mathrm{kg} \cdot \mathrm{ha}^{-1}\right.$ per $\left.3 \mathrm{week}^{-1}\right)$ & \\
0 & 0.94 \\
3.8 & 0.85 \\
7.6 & 0.79 \\
Source of variation & $P$ value \\
\hline $\mathrm{N}$ & 0.0001 \\
Ethephon & 0.0172 \\
$\quad$ Linear & 0.0041 \\
Quadratic & $\mathrm{NS}$ \\
$\mathrm{N} \times$ ethephon & $\mathrm{NS}$ \\
\hline${ }^{2}$ Nitrogen source was 34-0-0 ammonium nitrate \\
solution. \\
${ }^{\mathrm{y} C l i p p i n g y i e l d w a s ~ p o o l e d ~ o v e r n i n e ~ w e e k l y ~ s a m p l e s ~}$ \\
in both experiments.
\end{tabular}

season grasses following ethephon treatments (Eggens et al., 1989; Kane and Miller, 2003; McCullough et al., 2004). However, N inputs at $8 \mathrm{~kg} \cdot \mathrm{ha}^{-1} \cdot$ week $^{-1}$ improved bentgrass quality about $10 \%$ to $20 \%$ and $10 \%$ to $30 \%$ with ethephon applied at 3.8 and $7.6 \mathrm{~kg} \cdot \mathrm{ha}^{-1}$ per 3 weeks, respectively. Increasing routine $\mathrm{N}$ fertility may be an effective practice to reduce leaf chlorosis following ethephon applications. Routinely applying secondary and micronutrients, such as $\mathrm{Mg}$ and Fe, may also effectively reduce phytoxicity from ethephon applications and warrants further investigations.

Week by treatment interactions did not occur for clipping yield; therefore, results were pooled over the nine samples. Bentgrass fertilized with $8 \mathrm{~kg} \cdot \mathrm{ha}^{-1} \mathrm{~N}$ per week had $30 \%$ increased dry clipping yield (Table 2 ). Ethephon decreased clipping yield from the untreated by $10 \%$ and $16 \%$ at 3.8 and $7.6 \mathrm{~kg} \cdot \mathrm{ha}^{-1}$ per 3 weeks, respectively. Eggens et al. (1989) noted similar clipping yield reductions of creeping bentgrass, ranging $5 \%$ to $20 \%$, from repeated ethephon use at 0.8 to $3.2 \mathrm{~kg} \cdot \mathrm{ha}^{-1}$. The researchers noted that Poa annua clippings were reduced $20 \%$ to $40 \%$ from repeated applications of ethephon suggesting greater susceptibility to growth inhibition than creeping bentgrass. In other experiments, ethephon applied at five rates from 0 to $8 \mathrm{~kg} \cdot \mathrm{ha}^{-1}$ linearly reduced Poa annua clippings (Eggens and Wright, 1985) and inhibited Kentucky bluegrass leaf elongation by $75 \%$ (Poovaiah and Leopold, 1973).

Increasing ethephon rates significantly reduced root growth from the untreated turf after nine weeks (Table 3). Bentgrass root length was reduced $28 \%$ and $31 \%$ from ethephon at 3.8 and $7.6 \mathrm{~kg} \cdot \mathrm{ha}^{-1}$ per 3 weeks, respectively. Root mass after 9 weeks was reduced by about $35 \%$ from both ethephon rates. Similar root mass and root length restrictions have been observed on kentucky bluegrass and perennial ryegrass following ethephon applications (Eggens and Wright, 1985; Jiang and Fry, 1998). Bentgrass treated with $8 \mathrm{~kg} \cdot \mathrm{ha}^{-1} \mathrm{~N}$ per week averaged $12 \%$ and $11 \%$ reduced root length and root mass than turf fertilized with $4 \mathrm{~kg} \cdot \mathrm{ha}^{-1} \mathrm{~N}$ per week.

Although maintaining creeping bentgrass with higher $\mathrm{N}$ rates may reduce phytotoxicity following ethephon applications, increasing $\mathrm{N}$ rates may be agronomically detrimental to root growth. Heavier $\mathrm{N}$ fertilization generally decreases photosynthate partitioning to the root system, reducing reserve carbohydrates needed for root growth and maintenance (Beard, 1973; Hull, 1992). However, turfmanagersmaintaining creeping bentgrass putting greens with severe Poa annua infestations may have to compromise bentgrass root growth in order to provide acceptable putting green playing surfaces.
Leaf water content linearly increased with ethephon rates from week 2 to 9 (Table 4). Similarly, bentgrass fertilized with $8 \mathrm{~kg} \cdot \mathrm{ha}^{-1}$ $\mathrm{N}$ per week had greater leaf water content than $4 \mathrm{~kg} \cdot \mathrm{ha}^{-1} \mathrm{~N}$ per week, likely resulting from more actively growing tissue. Increased water content with ethephon applications contradicts dry clipping yield results; however, this may indicate a physiological response from ethephon use. Ethylene induction promotes lateral cell expansion (Taiz and Zeiger, 2002), thus higher water concentrations may accumulate in plant cells as a result. Consequently, increased leaf water content may create more succulent leaf tissue which may increase bentgrass susceptibility to injury and pathogen invasion.

Creeping bentgrass leaf morphological responses following ethephon applications may reduce leaf texture and putting green uniformity. Ethephon applications have shown to significantly reduce ball roll distances on a monostand creeping bentgrass putting green compared to untreated turf(McCullough et al., 2005). Effects of increased leaf water content on bentgrass leaf texture may explain reductions in putting green ball roll distances. Conversely, when Poa annua is the predominant species in a putting green, arresting seedhead production with ethephon may drastically improve ball roll distances and bentgrass leaf responses may not be a concern.

Table 3. Dry root mass and root length for 'L-93' creeping bentgrass after 9 weeks in two combined greenhouse experiments.

\begin{tabular}{|c|c|c|c|}
\hline $\begin{array}{l}\mathrm{N}^{\mathrm{z}} \\
\left(\mathrm{kg} \cdot \mathrm{ha}^{-1} \cdot \text { week }^{-1}\right)\end{array}$ & $\begin{array}{c}\text { Ethephon } \\
\left(\mathrm{kg} \cdot \mathrm{ha}^{-1} \text { per } 3 \text { week }^{\mathrm{s}}\right)\end{array}$ & $\begin{array}{c}\text { Dry } \\
\text { root } \\
\text { mass }^{y} \\
\left(\mathrm{~g} \cdot \mathrm{m}^{-2}\right)\end{array}$ & $\begin{array}{l}\text { Root } \\
\text { length } \\
(\mathrm{cm})\end{array}$ \\
\hline \multirow[t]{3}{*}{4} & 0 & 38 & 22 \\
\hline & 3.8 & 26 & 18 \\
\hline & 7.6 & 25 & 17 \\
\hline \multirow[t]{3}{*}{8} & 0 & 36 & 22 \\
\hline & 3.8 & 21 & 14 \\
\hline & 7.6 & 23 & 13 \\
\hline Source of variation & & & \\
\hline $\bar{N}$ & & NS & NS \\
\hline Ethephon & & 0.0013 & 0.0001 \\
\hline Linear & & 0.0018 & 0.0001 \\
\hline Quadratic & & 0.0290 & 0.0475 \\
\hline $\mathrm{N} \times$ ethephon & & NS & NS \\
\hline
\end{tabular}

${ }^{2}$ Nitrogen source was 34-0-0 ammonium nitrate solution.

${ }^{y}$ Roots were harvested from the entire container after 9 weeks.

${ }^{x}$ Root length was determined by measuring the distance from where roots were no longer present in the soil profile to the top of the container. 
Table4. Relative leaf water content of 'L-93' creeping bentgrass treated with nitrogen and ethephon in two combined greenhouse experiments.

\begin{tabular}{lcc}
\hline & $\begin{array}{c}\text { Ethephon } \\
\mathrm{N}^{z}\end{array}$ & $\begin{array}{c}\text { Leaf } \\
\text { water } \\
\text { content } \\
(\%)\end{array}$ \\
\hline 4 & 0 & 0 \\
& 3.8 & 6 \\
8 & 7.6 & 10 \\
& 0 & 4 \\
& 3.8 & 9 \\
Source of variation & 7.6 & 12 \\
$\mathrm{~N}$ & & $P$ value \\
Ethephon & & 0.0062 \\
Linear & & 0.0001 \\
Quadratic & & 0.0001 \\
$\mathrm{~N} \times$ ethephon & & $\mathrm{NS}$ \\
\hline
\end{tabular}

${ }^{2}$ Nitrogen source was $34-0-0$ ammonium nitrate solution.

yPercent leaf water content is relative to turf fertilized with $4 \mathrm{~kg} \cdot \mathrm{ha}^{-1} \mathrm{~N}$ per week and the 0 ethephon level. Results were pooled from week 2 to 9 over both experiments.

In another experiment with ethephon, Jiang and Fry (1998) noted the PGR increased perennial ryegrass quality under drought conditions. Ethephon, therefore, may effectively prepare turfgrasses for potentially stressful conditions, such as heat and drought stress. Further research is needed to address turfgrass physiological responses following ethephon applications under various environmental conditions.

In conclusion, applications of ethephon may be extremely phytotoxic to creeping bentgrass putting greens; however, routine $\mathrm{N}$ fertility may significantly influence bentgrass tolerances to ethephon. Although higher $\mathrm{N}$ rates reduce leaf chlorosis, repeat applications of ethephon and increased $\mathrm{N}$ have potential to restrict bentgrass root growth. These responses may limit the applicability of ethephon for creeping bentgrass putting greens.

\section{Literature Cited}

Beard, J.B. 1973. Turfgrass: Science and culture. Prentice-Hall, Englewood Cliffs, N.J.

Eggens, J.L. and C.P.M. Wright. 1985. Kentucky bluegrass and annual bluegrass response to ethephon. J. Amer. Soc. Hort. Sci. 110(5):609611.

Eggens, J.L., C.P.M. Wright, D.P. Murr, and K. Carey. 1989. The effect of ethephon on annual bluegrass and creeping bentgrass growth. Can. J. Plant Sci. 69:1353-1357.

Engel, R.E. and R.D. Ilnicki. 1969. Turf weeds and their control, p. 240-282. In: A.A. Hanson and F.V. Juska (eds.). Turfgrass. Amer. Soc. Agron. Monogr. 14.

Gelertner, W. and L.J. Stowell. 2001. Advances in Poa seedhead management. Golf Course Mgt. 69(10):49-53.

Hull, R.J. 1992. Energy relations and carbohydrate partitioning, p. 175-205. In: D.V. Waddington, R.N. Carrow, and R.C. Shearman (eds.). Turfgrass. Amer. Soc. Agron. Monogr. 32.

Jiang, H. and J. Fry. 1998. Drought responses of perennial ryegrass treated with plant growth regulators. HortScience 33:270-273.

Kane, R. and L. Miller. 2003. Field testing plant growth regulators and wetting agents for annual bluegrass seedhead suppression. USGA Green Sect. Record 41(7):21-26.

McCarty, B, T. Murphy, T. Whitwell, and F. Yelverton. 2005a. Turfgrass weeds, p. 663-703. In: L.B.
McCarty (ed.). Best golf course management practices. 2nd ed. Prentice-Hall, Upper Saddle River, N.J.

McCarty, B., C. Bigelow, A.H. Bruneau, and G. Landry. 2005b. Managing bentgrass/poa annua golf greens in stressful environments, p. 485-511. In: L.B. McCarty (ed.). Best golf course management practices. 2nd ed. Prentice-Hall, Upper Saddle River, N.J.

McCullough, P.E., H. Liu, and L.B. McCarty. 2005. Mowing operations influence creeping bentgrass putting green ball roll following plant growth regulator applications. HortScience 40:471-474

McCullough, P.E., H. Liu, L.B. McCarty, and T. Whitwell. 2005. Response of 'TifEagle' bermudagrass to seven plant growth regulators. HortScience 39:1759-1762.

Poovaiah, B.W. and A.C. Leopold. 1973. Effects of ethephon on growth of grasses. Crop Sci. 13:755-758.

SAS Institute. 1999. The SAS system for Windows. v. 8.2. SAS Inst., Cary, N.C.

Serek, M. and M.S. Reid. 2000. Role of growth regulators in the postharvest life of ornamentals, p. 147-174. In: A.S. Basra (ed.). 2000. Plant growth regulators in agriculture and horticulture: Their role and commercial uses. Food Products Press, Binghamton, N.Y.

Taiz L. and E. Zeiger. 2002. Plant physiology. 3rd ed Sinauer Associates, Sunderland, Mass.

Turner, T.R. and N.W. Hummell. 1992. Nutritional requirements and fertilization, p. 385-439. In: D.V. Waddington, R.N. Carrow, and R.C. Shearman (eds.). Turfgrass. Amer. Soc. Agron. Monogr. 32.

United States GolfAssociation Green Section Staff. 1993. USGA recommendations for a method of putting green construction. The 1993 Revision. USGA Green Sect. Record 31(2):1-3. 